\title{
Synthesis gas production with high hydrogen concentration aspen simulation
}

\author{
Abdalhamed A. E. Musbah ${ }^{1 *}$, Salah.M.Algoul ${ }^{2}$, Abdalbaset M.R. Algish ${ }^{3}$, Eisa A. \\ abdalaslam $^{4}$ \\ ${ }^{1,4}$ Chemical Engineering Department, Awlad Ali High Institute for Science and Technology, \\ Tarhuna, Libya \\ ${ }^{2}$ Chemical Engineering Department, The High Institute of Engineering Technology -Zliten, Libya \\ ${ }^{3}$ Chemical and Petroleum Department, The Higher Institute for Science and Technology, \\ Algaraboli, Libya \\ DOI: https://doi.org/10.21467/proceedings.2.30 \\ * Corresponding author email: almazuod@yahoo.com
}

\begin{abstract}
There is a growing need for hydrogen and future hydrogen economy becomes high on the scientific agenda, despite the "sustainable" routes are still too expensive; however, Steam reforming of hydrocarbons is the most feasible rout. This paper focuses on the production of Synthesis gas with high hydrogen concentration via process simulation using aspen plus simulator version 2006 and methane as a feedstock; the simulation process aimed mainly to produce synthesis gas rich in hydrogen with a minimum consumption of natural gas and agents of reforming and burning. An investigation of the effects of reactor (reformer) temperature, steam to natural gas (equivalence ratio) and the oxygen ratio in air on the composition of produced gases are conducted. The combustion reactor operated over a temperature range of $500-900{ }^{\circ} \mathrm{C}$ while varying equivalence ratio from 3:1 to 3:5. The results show that the hydrogen concentration in the produced gas increased rapidly with increasing reforming temperature and the best rang is $\left(750-850^{\circ} \mathrm{C}\right)$ where the highest conversion was at $850^{\circ} \mathrm{C}$. Low equivalence ratio $3: 1$ is not preferred because it results low hydrogen concentration produced in synthesis gas but equivalence ratio equal to $3: 3$ is preferred for synthesis process as it results complete combustion of methane present in the feed resulting higher percentage of $\mathrm{H}_{2}$ in the produced gas. In additional, if the content of $\mathrm{O}_{2}$ in the air used in the combustion reactor as reforming agent was increased the content of hydrogen in the produced synthesis gas increased and on the other hand the content of nitrogen which is an inert gas is decreased by approximately $(7.99 \%)$. However, $70 \% \mathrm{O}_{2}$ by volume content in the air stream ensures that the content of hydrogen (63.28\%) in compared with pure oxygen gives $63.57 \%$.
\end{abstract}

Keywords: Synthesis gas, hydrogen, simulation.

\section{Introduction}

The use of hydrogen for petrochemicals, fertilizers and as energy carrier in connection with renewable energy production will increase substantially in the next 5-10 years as even more

(C) 2018 Copyright held by the author(s). Published by AIJR Publisher in Proceedings of First Conference for Engineering

Sciences and Technology (CEST-2018), September 25-27, 2018, vol. 1.
This is an open access article under Creative Commons Attribution-NonCommercial 4.0 International (CC BY-NC 4.0) license, which permits any non-commercial use, distribution, adaptation, and reproduction in any medium, as long as the original work is properly cited. ISBN: $978-81-936820-5-0$ 
stringent environmental legislation is enforced, Low sulphur gasoline and diesel fuels will become mandatory and harmful emissions will be reduced drastically. Hydrogen will be required by refiners and specialty chemical manufacturers to meet the global need for cleaner products. The growing fuel cell market will be dependent on hydrogen as a primary fuel source [1]. However, the major sources of energy in the world are the traditional fossil fuels (oil, coal and natural gas) and on consequence of global economic development, especially in the recent decades led to a significant decrease in these non-renewable resources.

In addition, the increasing of energy demands will speed up the exhaustion of the finite fossil fuel, with the current proved reserves and flows, years of production left in the ground coal 148 years, oil 43 years, natural gas 61 years according to scientist's studies [2]

However, non-renewable resources of fossil fuels have led to serious energy crisis and environmental problems such as global warming pollutant emission and acid rain. Carbon dioxide is the main greenhouse gas. The major part of $\mathrm{CO}_{2}$ emissions is due to combustion of fossil fuels. In addition, combustion of fossil fuel produces toxic gases, such as $\mathrm{SO}_{2}, \mathrm{NO}_{\mathbf{x}}$ and other pollutants [3].

For these reasons the necessity importunate to find another substitute Where many efforts have been made to explore clean energy and renewable alternatives such as biofuels and hydrogen, Hydrogen can replace the conventional fossil fuels because hydrogen overcome fossil fuel and it has the highest energy to weight ratio compared to any fuel [4].

Besides using hydrogen as a source of energy, hydrogen can be used for various other purposes in different industries in hydrogenation process such as saturate compounds and crack hydrocarbons as well as in manufacturing of different chemicals like ammonia, methanol etc. [5]. Hydrogen considered as the "fuel of the future" because it is applicable to the technologies which are relating to fuel cells [6].

There are many methods to produce hydrogen but reforming natural gas is a current process of hydrogen production, economical and widely used, provides for short and medium - term energy security and environment friendly, however, producing high concentration synthesis gas is the main drawback of this process.

The reforming reactions correlated with the proprieties package for the reformer equipment are:

$$
\mathrm{CH}_{4}+\mathrm{H}_{2} \mathrm{O} \rightleftharpoons \mathrm{CO}+3 \mathrm{H}_{2}
$$

$$
\mathrm{CH}_{4}+2 \mathrm{H}_{2} \mathrm{O} \rightleftharpoons \mathrm{CO}_{2}+4 \mathrm{H}_{2}
$$

The combustion reaction correlated with the proprieties package for the combustor equipment is:

$$
\mathrm{CH}_{4}+2 \mathrm{O}_{2} \rightleftharpoons \mathrm{CO}_{2}+2 \mathrm{H}_{2} \mathrm{O}
$$


The equilibrium reaction correlated with the proprieties package for the all three equilibrium reactors is:

$$
\mathrm{CO}+\mathrm{H}_{2} \mathrm{O} \rightleftharpoons \mathrm{CO}_{2}+\mathrm{H}_{2}
$$

Steam reforming process involves the conversion of methane and water vapour into hydrogen and carbon monoxide the conversion is carried out at temperatures of 700 to $850{ }^{\circ} \mathrm{C}$ and pressures of 3 to 25 bars. The product contains approximately $12 \% \mathrm{CO}$ which can be further converted to $\mathrm{CO}_{2}$ and $\mathrm{H}_{2}$ through the water-gas shift reaction [7].

In this paper, a steam reforming process studied and simulated to reach the maximum hydrogen concentration in produced synthesis gas. Thus, one of the advantages of these simulations is to produce hydrogen rich fuel gas and to reduce the percentage of unwanted gas for fuel cell system and environment.

Table1: thermodynamic characteristics of the reactions presented above [8]:

\begin{tabular}{|c|c|c|}
\hline & $\begin{array}{c}\text { standard heat of reaction }(\mathrm{KJ} / \mathrm{Kgmol}) \\
\text { at } 25^{\circ} \mathrm{C}\end{array}$ & $\begin{array}{c}\text { equilibrium constant } \\
\text { at } 800^{\circ} \mathrm{C}\end{array}$ \\
\hline reaction 1 & $2.1 \times 10^{5}$ & 0.0313 \\
\hline reaction 2 & $1.6 \times 10^{5}$ & 0.0166 \\
\hline reaction 3 & $-8 \times 10^{5}$ & $1.8 \times 10^{17}$ \\
\hline reaction 4 & $-4.2 \times 10^{4}$ & 4.063 \\
\hline
\end{tabular}

The values for the proprieties of the gaseous phases implied in the reforming process were chosen from specialty literature. Table 2 shows the initial condition of the streams [9].

Table 2: the initial stoichiometric composition and conditions of first iteration simulation

\begin{tabular}{|c|c|c|c|c|}
\hline component mole fraction $\%$ & natural gas & Air & Combustion steam & reforming steam \\
\hline $\mathrm{H}_{2} \mathrm{O}$ & - & - & 1 & 1 \\
\hline $\mathrm{CH}_{4}$ & 1 & - & - & - \\
\hline $\mathrm{CO}$ & - & - & - & - \\
\hline $\mathrm{CO}_{2}$ & - & - & - & - \\
\hline $\mathrm{H}_{2}$ & - & - & - & - \\
\hline $\mathrm{N}_{2}$ & - & 0.79 & - & - \\
\hline $\mathrm{O}_{2}$ & - & 0.21 & 400 & 500 \\
\hline Temperature ${ }^{\circ} \mathrm{C}$ & 25 & 350 & 1 & 1 \\
\hline
\end{tabular}

\section{Process Description}

Four reactors needed in a typical process of synthesis gas production [3]. However, the proposed simulation model requires three reactors, firstly, the Reformer: The reformer is an equilibrium reactor, in which most of the methane is reacted with steam to produce hydrogen, 
carbon monoxide and carbon dioxide. The outlet gas will also contain the un-reacted methane and excess water vapour from the steam. The two reforming reactions are endothermic therefore heat must supply into the reactor to maintain the reactor temperature. The temperature of combustor feed is simulated to find the best temperature, which maximizes the reacted methane.

Secondly, the Combustor: the combustor is a conversion reactor where, the feed streams include the reformer product and an air stream. The oxygen in the air almost consumed in the combustion of the rest of unreformed methane to produce carbon monoxide and carbon dioxide. Depending on the content of oxygen in the air, the synthesis gas composition is changing.

Finally, Shift reactors: the shift reactors is an equilibrium reactor within the water-gas shift reaction occurs. In the combustor shift reactor the produced carbon monoxide is converted to carbon dioxide and more hydrogen is produced. The natural gas is reformed in a conversion reactor (Reformer) when it is combined with steam.

The proposed flow sheet of the feedstock, architecture of the model and the intermediary or final products are shown in figure 1.

\section{$3 \quad$ Methodology}

This conceptual model was realized in HYSYS software according with the existing technologies. The Soave Redlich kwong (SRK) equation of state has extensively used in calculating phase and reaction equilibrium. It gives good agreement with experiment so it was used to calculating the reaction equilibrium to correct the non-ideality of the gas mixture .

The synthesis gas Production was simulated using the Aspen Hysys V6.software where the following parameters simulated to find out their effects on purity and productivity of produced synthesis gas, and to increase the hydrogen produced volume fraction. These parameters are including reformer temperature, the mole ratio of natural gas to air (equivalence Ratio) used to burn it, the reforming / combustion agent (mixture steam - air with different concentration of $\left.\mathrm{O}_{2}\right)$; and the volumetric composition ( $\mathrm{v} / \mathrm{v} \%$ ) of the gases resulting from the reforming / combustion process of natural gas. The process takes place at atmospheric pressure. 


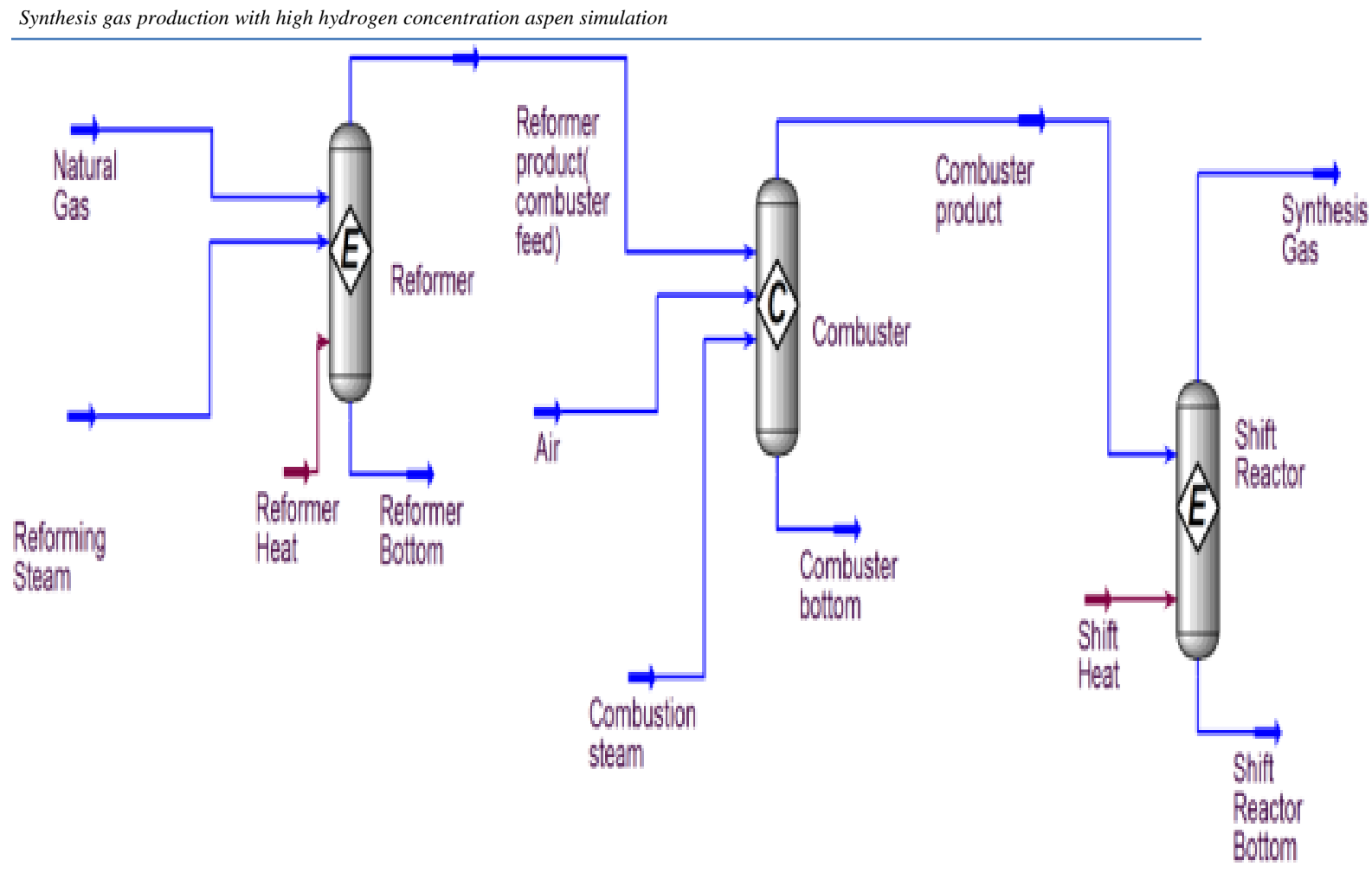

Figure 1: synthesis process flow diagram

\section{$4 \quad$.Results and Discussion}

To initialize the process and to run the simulation, the values for the proprieties of the gaseous phases implied in the reforming processes were chosen from specialty literature and shown in table 2 .

\subsection{Effects of varying reformer temperature on methane reforming process and produced synthesis gas composition $\left(\mathrm{CO} \&+\mathrm{H}_{2}\right)$ at constant equivalence ratio.}

Form first iteration simulation for stoichiometric mole quantity of reforming process at inlet conditions it can be clearly seen that by increasing the reforming temperature the conversion of methane increased. However, the volume fraction of $\mathrm{CO}$ is increased and this will make the process need more shifting reaction in the third reactor to convert $\mathrm{CO}$ to $\mathrm{CO}_{2}$ and $\mathrm{H}_{2}$. For this reason the equilibrium reaction at $850^{\circ} \mathrm{C}$ was chosen for the simulation where it gives highest methane

Conversion and in next reactor the produced Carbone monoxide will be eliminated. 
Musbah et al., CEST-2018, AIJR Proceedings 2, pp.254-262, 2018

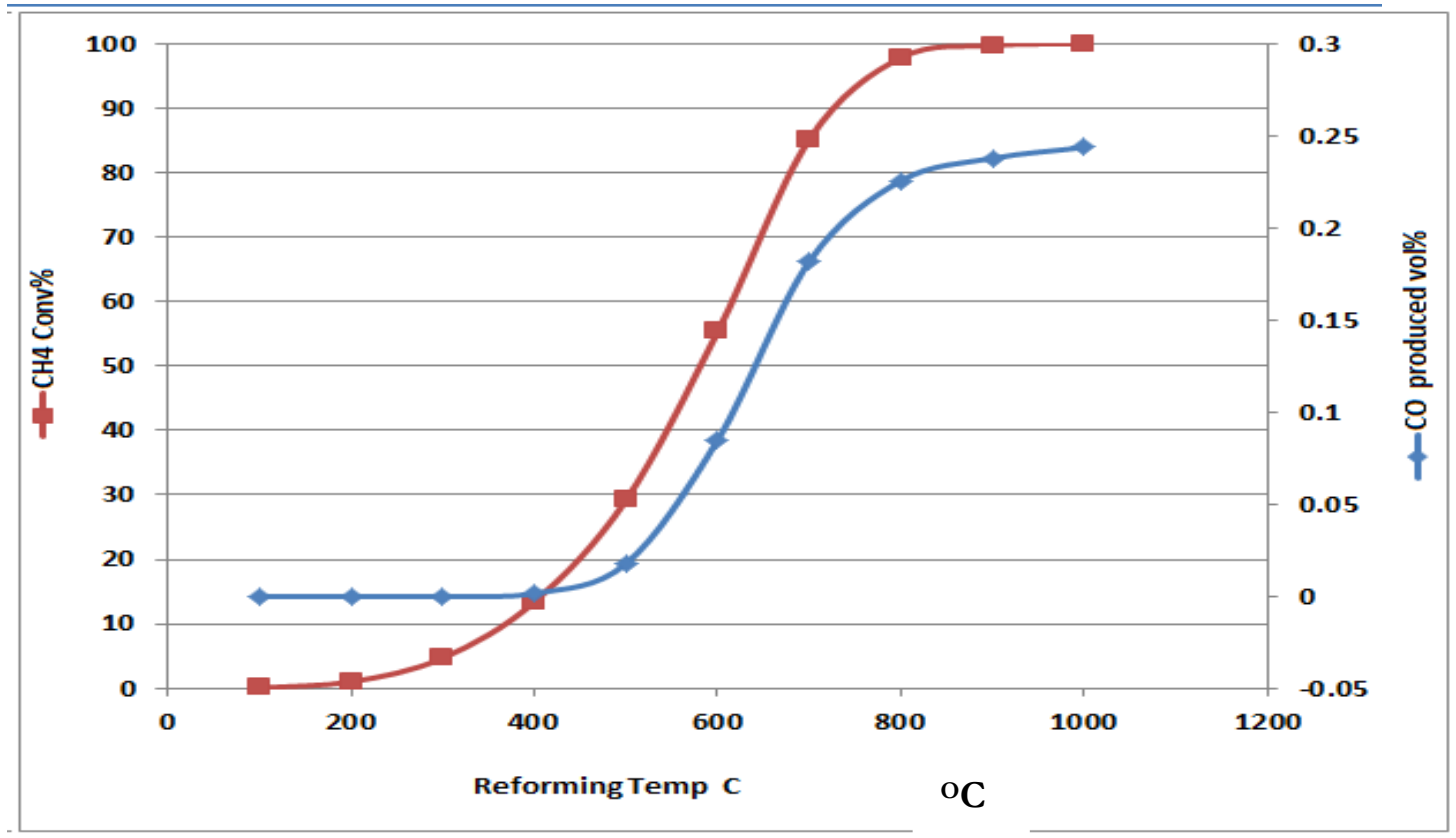

Figure 2: Reforming temperature effects on methane conversion and produced CO Vol fraction.

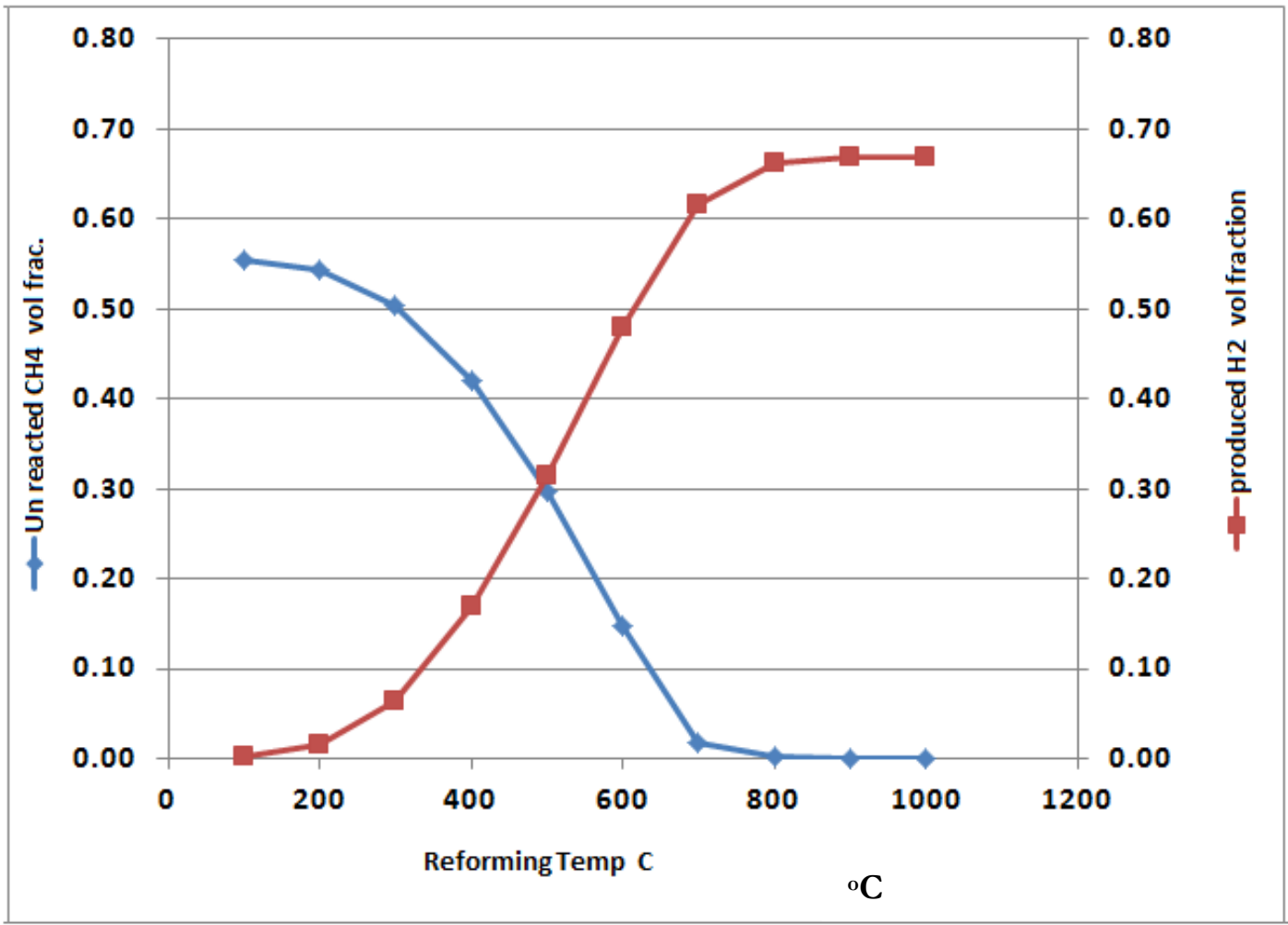

Figure3: Reforming temperature effects on produced hydrogen and unreacted methane vol fraction

Proceedings of First Conference for Engineering Sciences and Technology (CEST-2018), vol. 1 259 
Synthesis gas production with high hydrogen concentration aspen simulation

From figures above, when temperature become greater than $700^{\circ} \mathrm{C}$, the volume fraction of unreacted methane approach 1 or 2 volumes present and the produced hydrogen reach the maximum value. The addition of oxygen in the second reactor serves to the purpose of ensuring that the excess of methane from the natural gas stream is consumed and since reforming reactions, is an exothermic reaction, the product gas composition is sensitive toward temperature change and it was observed that the concentration of $\mathrm{H}_{2}$ increases with increase in temperature. Higher temperature provides more favourable condition for steam reforming of methane therefore, with increasing in temperature the concentration of methane decreases in the product gas and this is attributed to increase in concentration of hydrogen. On the other hand, the $\mathrm{CO}_{2}$ concentration decreases with increase in temperature because higher temperature favours endothermic formation of $\mathrm{CO}$ from $\mathrm{CO}_{2}$ via reverse reaction.

\subsection{Effects of varying equivalence ratio (steam to methane) on produced synthesis gas composition $\left(\mathrm{CO} \& \mathrm{H}_{2}\right)$}

Equivalence ratio is the most important parameter of synthesis process. The effect of equivalence ratio on product synthesis gas composition was studied in the range 3:1 to 3:5 at $850{ }^{\circ} \mathrm{C}$. Figure 4 shows $\mathrm{CO}_{2}$ volume fraction is directly proportional to the equivalence ratio to specific limit. Equivalence ratio (methane to steam equal to 2 or 3 ) gives the highest hydrogen volume fraction, and small carbon dioxide volume produced.

With increasing in equivalence ratio, more complete synthesis process takes place producing more $\mathrm{H}_{2}$ and this leads to decrease in concentration of $\mathrm{CO}$, so less $\mathrm{CO}$ is produced from water gas shift reaction. However, it can increase the carbon monoxide and in this case, it needs to be eliminated in equilibrium reactor and convert it to $\mathrm{CO}_{2}$ according to the equilibrium reaction.

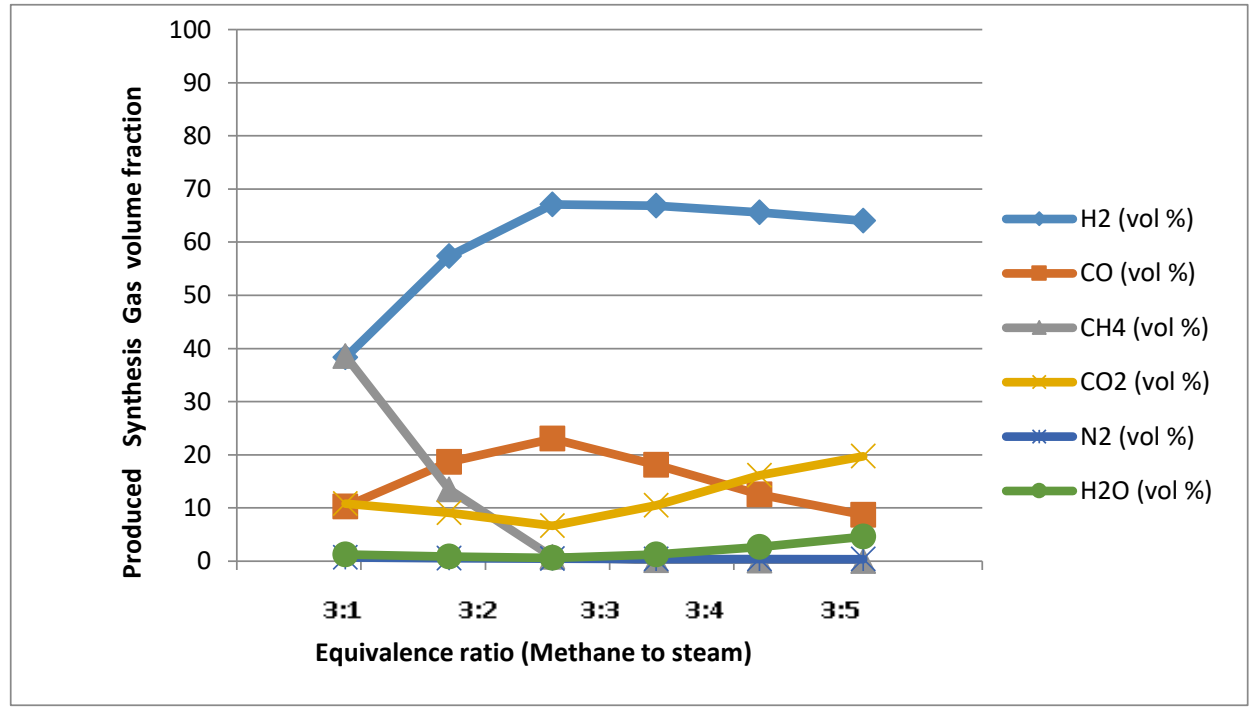

Figure 4: Simulated product gas composition (volume \%) at different temperatures 
Musbah et al., CEST-2018, AIJR Proceedings 2, pp.254-262, 2018

\subsection{Effects of varying oxygen mole fraction in air on produced synthesis gas composition at different equivalence ratio}

In the conversion reactor, if the temperature in reformer reactor is less than $800{ }^{\circ} \mathrm{C}$ some amount of methane can be unconverted and in this case it needs to convert into $\mathrm{CO}_{2}$ and $\mathrm{H}_{2} \mathrm{O}$ via enhancing the combustion reaction. In the case of steam to methane used was 3:2 at temperature $750{ }^{\circ} \mathrm{C}$, and air with different content in $\mathrm{O}_{2}$ varied from 21 volumes present to $100 \%$ were used, the simulation process of the natural gas reforming gives the follow results for the ratio of Oxygen required to burnet the unreacted methane is equal to $2: 1$ stoichiometric.

If the concentration of $\mathrm{O}_{2}$ in the air used in the second reactor, combustor reactor increased, the concentration of hydrogen in synthesis gas product will increase and as a secondary effect will decrease the concentration of nitrogen, which is an inert gas where, for a concentration of $50 \% \mathrm{O}_{2}$ it was obtained the best results of the simulation process: $63 \% \mathrm{H}_{2}$ and $4.03 \% \mathrm{~N}_{2}$. It can be recommended to balance the amount of air to combust the remains unreacted $\mathrm{CH} 4$ and the amount of water required in the equilibrium reactor to eliminate the unreacted methane, it recommended that it is better to carry out the reforming reaction in temperature about $850 \circ \mathrm{C}$ and the required amount of air can be cut down to become near zero, however, the results are shown in table (3), where the best equivalence ratio is $3: 3$.

Table3: the simulated volume fraction of produced synthesis gases

\begin{tabular}{|c|c|c|c|c|c|c|c|}
\hline Parameters & $\begin{array}{l}\mathrm{CH}_{4} \\
\mathrm{Vol} \%\end{array}$ & $\mathrm{H}_{2} \mathrm{O} \quad \mathrm{Vol} \%$ & $\mathrm{CO} \mathrm{Vol} \%$ & $\mathrm{CO}_{2} \mathrm{Vol}^{1} \%$ & $\mathrm{H}_{2} \mathrm{Vol} \%$ & $\mathrm{~N}_{2} \mathrm{Vol} \%$ & $\mathrm{O}_{2} \mathrm{Vol}^{0} \%$ \\
\hline equivalence ratio & \multicolumn{7}{|c|}{$3: 1$} \\
\hline Air with $21 \%$ Vol O2 & 0.3427 & 0.035 & 0.0428 & 0.1334 & 0.3538 & 0.0926 & 0.000 \\
\hline Air with $50 \%$ Vol O2 & 0.3204 & 0.0507 & 0.0383 & 0.1691 & 0.3622 & 0.0593 & 0.00 \\
\hline Air with $70 \% \mathrm{Vol} \mathrm{O} 2$ & 0.3050 & 0.0623 & 0.0361 & 0.1930 & 0.3677 & 0.0359 & 0.00 \\
\hline Air with $100 \% \mathrm{Vol} O 2$ & 0.2815 & 0.0807 & 0.0337 & 0.2284 & 0.3757 & 0.000 & 0.00 \\
\hline equivalence ratio & \multicolumn{7}{|c|}{$3: 2$} \\
\hline Air with $21 \%$ Vol O2 & 0.1322 & 0.0201 & 0.1111 & 0.1329 & 0.5293 & 0.0744 & 0.000 \\
\hline Air with $50 \%$ Vol O2 & 0.1117 & 0.0290 & 0.1010 & 0.1707 & 0.5404 & 0.0473 & 0.000 \\
\hline Air with $70 \%$ Vol O2 & 0.0974 & 0.0357 & 0.0951 & 0.1955 & 0.5477 & 0.0285 & 0.00 \\
\hline Air with $100 \% \mathrm{Vol} \mathrm{O} 2$ & 0.0760 & 0.0467 & 0.0877 & 0.2313 & 0.5583 & 0.000 & 0.00 \\
\hline equivalence ratio & \multicolumn{7}{|c|}{$3: 3$} \\
\hline Air with $21 \% \mathrm{Vol} \mathrm{O} 2$ & 0.0109 & 0.0178 & 0.1483 & 0.1331 & 0.6265 & 0.0634 & 0.000 \\
\hline Air with $50 \%$ Vol O2 & 0.0072 & 0.0192 & 0.1466 & 0.1409 & 0.6309 & 0.0403 & 0.0150 \\
\hline Air with $70 \%$ Vol O2 & 0.0072 & 0.0193 & 0.1470 & 0.1413 & 0.6328 & 0.0242 & 0.0281 \\
\hline Air with $100 \%$ Vol O2 & 0.0072 & 0.0194 & 0.1477 & 0.1420 & 0.6357 & 0.000 & 0.048 \\
\hline equivalence ratio & \multicolumn{7}{|c|}{$3: 4$} \\
\hline Air with $21 \% \mathrm{Vol} \mathrm{O} 2$ & 0.1015 & 0.0132 & 0.1481 & 0.1075 & 0.5739 & 0.0558 & 0.000 \\
\hline Air with $50 \% \mathrm{Vol} \mathrm{O} 2$ & 0.0858 & 0.0186 & 0.1380 & 0.1390 & 0.5831 & 0.0354 & 0.000 \\
\hline Air with $70 \% \mathrm{Vol} \mathrm{O} 2$ & 0.075 & 0.0227 & 0.1318 & 0.1600 & 0.5893 & 0.0213 & 0.000 \\
\hline Air with $100 \%$ Vol O2 & 0.0588 & 0.0293 & 0.1233 & 0.1903 & 0.5984 & 0.0000 & 0.000 \\
\hline
\end{tabular}

Proceedings of First Conference for Engineering Sciences and Technology (CEST-2018), vol. 1 
Synthesis gas production with high hydrogen concentration aspen simulation

The oxygen from the air is consumed in an exothermic combustion reaction while the inert nitrogen passes through the system but if the content of oxygen in the air is raised, the effect is increasing of hydrogen content in the synthesis gas and decreasing the nitrogen content, these effects are desirable because the hydrogen is the final product and nitrogen is a useless inert gas. It gives the highest produced hydrogen volume fraction but in contrast it is clearly seen that the volume fraction of un converted carbon oxide is greater than some others, therefore, this process has a complexity that make it not easy to optimize the required amount using the simple software.

\section{Conclusions}

Using ASPEN PLUS simulator, a model for synthesis gas production in an atmospheric process was simulated using natural gas (Methane) as feed material. A series of simulations were carried on to investigate the effect of temperature, equivalence ratio on produced synthesis gas. The volume percentages of $\mathrm{H}_{2}, \mathrm{CO}, \mathrm{CH}_{4}$ and $\mathrm{CO}_{2}$ were calculated, the results showed that, the hydrogen concentration in the product gas increases rapidly with increase in temperature $\left(750-850^{\circ} \mathrm{C}\right)$. Low equivalence ratio $3: 1$ is not preferred as it results low hydrogen concentration produced in synthesis gas However, Equivalence ratio 3:3 is preferred for synthesis process as it results complete combustion of methane present in the feed, resulting higher percentage of $\mathrm{H}_{2}$ in the product gas. High steam to methane ratio results higher water gas shift reaction and this leads to better yield of hydrogen but much higher steam flow rates will have an opposing effect on producing higher CO produced which need higher efficient technique to be separated. In additional, if the content of $\mathrm{O}_{2}$ in the air used to the second reactor as reforming agent was increased, the content of hydrogen in the produced synthesis gas is higher and also the content of nitrogen which is an inert gas is decreased where it reaches $(7.99 \%)$. However, $70 \% \mathrm{O}_{2}$ by volume content in the air stream ensure that, the content of hydrogen $(63.28 \%)$ in compared with pure oxygen gives $63.57 \%$.

\section{References}

[1] Niels R. Udengaard, hydrogen production by steam reforming of hydrocarbons, Prepr. Pap. -Am. Chem. Soc., Div. Fuel Chem. 2004, 49(2), 907. El Camino Real, Suite 300.Houston, Texas 77058

[2] E. Rytter, Method and reactor for reformation of natural gas and simultaneous production of hydrogen, 2001

[3] M.R. Beychok, Process and environmental technology for producing SNG and liquid fuels,U.S. EPA report EPA-660/275-011, 1975

[4] A. Hartstein, Hydrogen production from natural gas, 2003

[5] M. Feidt, Energy efficiency and environment, U.P.B. Sci. Bull., Series C, Vol. 72, Iss. 1, 39-53, 2010

[6] S.C. Amendola, M. Binder, M.T. Kelly, P.J. Petillo, S.L. Sharp-Goldman, Advances in Hydrogen Energy, 69-86, 2002. S. Gagnon, Hydrogen. Jefferson Lab., 2008

[7] Riis T., Hagen E. F., Vie P. J. S. and Ulleberg O., Hydrogen production and storage R\&D: priorities and gaps. Paris, IEA Publications, 2006

[8] C. Basagianis, X.E. Verykos, Production of Hydrogen from Biomass via Steam Reforming of Bio-oil, Proceedings International Hydrogen Energy Congress and Exhibition IHEC 2005, Istanbul.

[9] Nath K. and Das D., Hydrogen from biomass, Current Science, vol. 85, No. 3, (2003): pp. 265-271 